\title{
Partial purification and preparation of bovine lactoperoxidase and characterization of kinetic properties of its immobilized form incorporated into cross-linked alginate films
}

\author{
Çiğdem Mecitoğlu, Ahmet Yemenicioğlu* \\ Department of Food Engineering, Faculty of Engineering, Izmir Institute of Technology, Gülbahçe Köyü, Urla, 35430 İzmir, Turkey
}

Received 22 September 2005; received in revised form 9 November 2006; accepted 9 November 2006

\begin{abstract}
Lactoperoxidase (LPS), purified directly from bovine rennet whey by Toyopearl-SP cation-exchange chromatography and lyophilized by using dextran as supporting material, maintained almost 70 and $60 \%$ of its activity after almost 2 and 5 months storage at $-18{ }^{\circ} \mathrm{C}$, respectively. Incorporation of the prepared LPS into alginate films between 0.08 and $0.69 \mathrm{mg} / \mathrm{cm}^{2}\left(516-4325 \mathrm{U} / \mathrm{cm}^{2}\right) \mathrm{caused} \mathrm{the} \mathrm{immo-}$ bilization of most of the enzyme and gave films with LPS activity between 0.05 and $2.8 \mathrm{U} / \mathrm{cm}^{2}$, determined in the presence of $8 \mu \mathrm{M} \mathrm{H} \mathrm{H}_{2}$. Between 2 and $24 \mu \mathrm{M} \mathrm{H}_{2} \mathrm{O}_{2}$ concentrations, a two-fold increase in $\mathrm{H}_{2} \mathrm{O}_{2}$ concentration caused 1.5-2.5-fold increase in LPS activity of films incorporated with $0.24-0.28 \mathrm{mg} / \mathrm{cm}^{2}\left(1200 \mathrm{U} / \mathrm{cm}^{2}\right)$ LPS. The $Q_{10}$ and $E_{\mathrm{a}}$ of immobilized enzyme activity between 4 and $16^{\circ} \mathrm{C}$ were 1.69 and $34.6 \mathrm{~kJ} / \mathrm{mol}$, respectively. However, in the $16-30^{\circ} \mathrm{C}$ range, the temperature change had almost no effect on LPS activity of films. The optimal activity of immobilized LPS was observed at $\mathrm{pH} 6.0$, but the enzyme maintained $30-85 \%$ of its activity between $\mathrm{pH} 3.0$ and 7.0. The immobilized LPS also had a high stability between $\mathrm{pH} 4.0$ and 6.0. The results of this study showed the good potential of LPSincorporated alginate films in forming a natural antimicrobial mechanism in different foods.
\end{abstract}

(c) 2006 Elsevier Ltd. All rights reserved.

Keywords: Lactoperoxidase; Purification; Immobilization; Characterization; Alginate films; Antimicrobial packaging

\section{Introduction}

The increased demand for easily prepared minimally processed fresh produce and the related increase of food-borne microbial outbreaks (De Roever, 1998) have intensified the research on antimicrobial packaging technologies (Suppakul, Miltz, Sonneveld, \& Bigger, 2003). Different chemicals, such as organic or inorganic acids, metals, alcohols, ammonium compounds or amines, can be incorporated into plastic or biodegradable packaging materials as antimicrobials (Appendini \& Hotchkiss, 2002; Suppakul et al., 2003). However, due to the health concerns of consumers related to chemical preservatives and environmental problems associated with the use of

\footnotetext{
${ }^{*}$ Corresponding author. Tel.: +90 232 7506292; fax: +90 2327506196.

E-mail address: ahmetyemenicioglu@iyte.edu.tr (A. Yemenicioğlu).
}

plastic packaging materials, there is an increasing demand for the food industry to use natural biopreservatives with edible and/or biodegradable packaging materials (Appendini \& Hotchkiss, 2002; Quintavalla \& Vicini, 2002). Different materials employed to obtain edible packaging films include cellulose derivatives, zein, carrageenan, alginate, and whey proteins (Cha, Choi, Chinnan, \& Park, 2002; Han, 2000; Padgett, Han, \& Dawson, 1998; Quintavalla \& Vicini, 2002; Suppakul et al., 2003). In most of the edible materials, the film formation occurs under mild conditions and this protects biopreservatives from denaturing effects, e.g. from classical thermal polymer processing methods, extrusion and injection molding (Appendini \& Hotchkiss, 2002; Han, 2000; Suppakul et al., 2003). Thus, the incorporation of biopreservatives into biodegradable films is generally more suitable than their incorporation into plastic films. 
The most frequently used biopreservatives for antimicrobial packaging are lysozyme and nisin (Cha et al., 2002; Dawson, Hoffman, \& Han, 2000; Hoffman, Han, \& Dawson, 2001; Janes, Kooshesh, \& Johnson, 2002; Padgett et al., 1998; Padgett, Han, \& Dawson, 2000; Park, Daeschel, \& Zhao, 2004; Teerakarn, Hirt, Acton, Rieck, \& Dawson, 2002). These biopreservatives are effective mainly on $\mathrm{Gr}(+)$ bacteria. However, they become effective also on Gr (-) bacteria when combined with chelating agents such as EDTA (Branen \& Davidson, 2004; Padgett et al., 2000). The other biopreservatives that may be used in antimicrobial packaging are bacteriocins, such as pediocin and lacticin, and antimicrobial enzymes, such as chitinase and glucose oxidase (Labuza \& Breene, 1989; Suppakul et al., 2003). Recently, different studies have also been conducted on the use of a lactoperoxidase (LPS)-thiocyanate- $\mathrm{H}_{2} \mathrm{O}_{2}$ antimicrobial system in food preservation. The LPS system is part of the natural preservation system that exists in milk. Thus, addition of thiocyanate and/or $\mathrm{H}_{2} \mathrm{O}_{2}$ to milk, to activate naturally occurring LPS, is used to improve microbial quality of milk and cheese (Seifu, Buys, \& Donkin, 2004; Seifu, Buys, \& Donkin, 2005). The addition of LPS and other components of this antimicrobial system to thermally processed skim milk (Zapico, Medina, Gaya, \& Nunez, 1998), meat and vegetable products (Elliot, McLay, Kennedy, \& Simmonds, 2004; Kennedy, O'Rourke, McLay, \& Simmonds, 2000; Touch, Hayakawa, Yamada, \& Kaneko, 2004) and prevention of the development of pathogenic bacteria have also been studied. The studies related to use of LPS in antimicrobial packaging, on the other hand, are new and very limited. In their detailed review, Suppakul et al. (2003) suggested the use of LPS in antimicrobial packaging. Recently, the LPS was incorporated into edible whey protein films and tests of these films on different microorganisms and smoked salmon showed the good potential of this enzyme for use in antimicrobial packaging (Min \& Krochta, 2005a; Min, Harris, \& Krochta, 2005b; Min, Harris, \& Krochta, 2005c). The mechanism of the antimicrobial action of LPS is based on conversion of thiocyanate $\left(\mathrm{SCN}^{-}\right)$to antimicrobial products, such as hypothiocyanite $\left(\mathrm{OSCN}^{-}\right)$ion, hypothiocyanous acid (HOSCN) and some other highly reactive and short-lived oxidation products in the presence of $\mathrm{H}_{2} \mathrm{O}_{2}$ (Pruitt, Tenovuo, Andrews, \& McKane, 1982). This system generally shows a bactericidal effect on Gr (-) bacteria and a bacteriostatic effect on $\mathrm{Gr}(+)$ bacteria (Seifu et al., 2005). Also, it has antifungal (Jacob, Antony, Sreekumar, \& Haridas, 2000) and antiviral (Pakkanen \& Aalto, 1997; Seifu et al., 2005) activities. The synergistic effect of LPS with nisin has also been demonstrated (Boussouel, Mathieu, Revol-Junelles, \& Milliere, 2000; Dufour, Simmonds, \& Bramer, 2003; Zapico et al., 1998).

In this work, LPS was partially purified, directly, from bovine whey by fast flow cation-exchange chromatography and prepared (with lyophilization) by using dextran as supporting material. The obtained enzyme was then tested for its storage stability, incorporated into alginate films and its affinity for alginate films; kinetic characteristics important for its potential use in antimicrobial food packaging were determined. The alginate films are frequently used for coating of meat, poultry and fish (Lindstrom, Morimoto, \& Cante, 1992). Thus, the data obtained in this study help to create a natural antimicrobial system in these products.

\section{Materials and methods}

\subsection{Materials}

Whole milk samples used to produce LPS enzyme were obtained at 2-2.5 month intervals from the same Holstein cow of a local farm in Urla, Izmir (Turkey). Toyopearl sulphopropyl (SP) cation-exchanger (SP-550C, fast flow, size: $100 \mu \mathrm{m})$ was obtained from Supelco (Bellefonte, PA, USA). Dialysis tubes (cut off: $12000 \mathrm{MW}$ ), dextran (from Leuconostoc mesenteroides, $73.200 \mathrm{MW})$, ABTS (2,2azino-bis-(3-ethylbenz-thiazoline-6-sulfonic acid)) and the sodium salt of alginic acid (from Macrocystis pyrifera, viscosity of $2 \%$ solution at $25{ }^{\circ} \mathrm{C}$ is $3500 \mathrm{cpc}$ ) were obtained from Sigma Chem. Co. (St. Louis, Mo, USA). Rennet was obtained from ICN Biomedicals Inc. (Aurora, Ohio, USA).

\subsection{Partial purification of LPS}

For purification of LPS from bovine whey the method of Ye, Yoshida, and $\mathrm{Ng}$ (2000) was used with slight modifications. The skim milk was obtained by centrifugation of $1 \mathrm{~L}$ of whole milk at $5000 \mathrm{~g}$ for $20 \mathrm{~min}$ at $30^{\circ} \mathrm{C}$. The skim milk was then filtered from cheese-cloth, warmed up to $37^{\circ} \mathrm{C}$ in an incubator and $90 \mathrm{mg}$ rennet were added to $900 \mathrm{ml}$ of the skim milk. After $1 \mathrm{~h}$ at $37^{\circ} \mathrm{C}$, the precipitates in whey were separated by filtration through a cheese-cloth and centrifugation at $10,000 \mathrm{~g}$ for $25 \mathrm{~min}$ at $4{ }^{\circ} \mathrm{C} .400 \mathrm{ml}$ of the clarified whey were then loaded on to a $11.5 \times 2.8 \mathrm{~cm}$ Toyopearl-SP column previously equilibrated with $0.05 \mathrm{M} \mathrm{Na}$ phosphate buffer at $\mathrm{pH}$ 6.5. The column was first washed with $500 \mathrm{ml}$ of the equilibration buffer and then eluted with a linear gradient of $600 \mathrm{ml}$ of $0-0.55 \mathrm{M}$ $\mathrm{NaCl}$ prepared in the same buffer. $10 \mathrm{ml}$ fractions collected from the column were assayed for their absorbance at $280 \mathrm{~nm}$ and LPS activity. This study was conducted by using LPS from three different purification studies. In the first purification study, the activity profile of LPS eluted was monitored quantitatively, as described in Section 2.4., whereas, in the other studies, it was monitored qualitatively by using the same reaction mixture.

\subsection{Preparation of LPS and test of its stability}

For the preparation of LPS, the enzyme containing fractions collected from the column were pooled and dialyzed for $24 \mathrm{~h}$ at $4{ }^{\circ} \mathrm{C}$. The dialyzed enzyme was then lyophilized in a Labconco freeze-dryer (FreeZone 61, Kansas City, MO, USA), working approximately at $-47^{\circ} \mathrm{C}$ collector 
temperature and $50-100 \times 10^{-3} \mathrm{mBar}$ vacuum, after dissolving $250-300 \mathrm{mg}$ of dextran in the dialyzed enzyme extract as a supporting material. The sample container volume was two to three times the sample volume. The stability of the LPS produced by this method was determined by monitoring of enzyme activity during frozen storage at $-18{ }^{\circ} \mathrm{C}$. The preparation was dissolved in distilled water and its activity was determined as described in Section 2.4.

\subsection{Determination of soluble LPS activity}

The activity of soluble LPS was determined spectrophotometrically by using a Shimadzu (Model 2450, Tokyo, Japan) spectrophotometer equipped with a constant temperature cell holder working at $30^{\circ} \mathrm{C}$. The reaction mixture was formed by mixing $2.3 \mathrm{ml}$ of $0.65 \mathrm{mM}$ ABTS prepared in $0.1 \mathrm{M} \mathrm{Na}$ phosphate buffer at $\mathrm{pH} 6.0,0.1 \mathrm{ml}$ of enzyme solution and $0.1 \mathrm{ml}$ of $0.2 \mathrm{mM} \mathrm{H} \mathrm{H}_{2} \mathrm{O}_{2}$ solution. All components of reaction mixture were brought to $30^{\circ} \mathrm{C}$ before mixing. The increase in absorbance was monitored at $412 \mathrm{~nm}$ for $5 \mathrm{~min}$ and enzyme activity, calculated from the slope of the initial linear portion of absorbance vs. time curve, was expressed as units $(0.001$ absorbance change in $1 \mathrm{~min}$ ). The average of three measurements was used to calculate soluble enzyme activity.

\subsection{Preparation of films}

To prepare films, $0.62-5.2 \mathrm{mg}$ of LPS preparation was dissolved per gram of $2 \%(\mathrm{w} / \mathrm{v})$ alginic acid solution by mixing slowly with a magnetic stirrer. $10 \mathrm{~g}$ portions of this solution were then spread onto glass Petri dishes $(9.8 \mathrm{~cm}$ in diameter). The Petri dishes were dried at room temperature for three days and $0.8 \mathrm{ml}$ of $0.3 \mathrm{M} \mathrm{CaCl}_{2}$ was pipetted into them to cross-link the dried films. Before being assayed for LPS activity, the films obtained were peeled from the Petri dishes and immersed in a beaker containing $50 \mathrm{ml}$ distilled water for $30 \mathrm{~s}$, to remove excessive $\mathrm{CaCl}_{2}$ that causes precipitations during LPS activity measurement. The average thickness of a cross-linked and dried control film (LPSfree) prepared by this method was determined by a scanning electron microscope (Philips XL 30S FEG, FEI Company, Eindhoven, Netherlands) as $12.8 \pm 1.6 \mu \mathrm{m}$.

\subsection{Determination of immobilized LPS activity in films}

To determine the immobilized LPS activity in films, the obtained cross-linked and washed alginate films were carefully halved with a clean razor. A film half (area: $37.7 \mathrm{~cm}^{2}$ ) was placed into a glass Petri dish containing $23 \mathrm{ml}$ of $0.65 \mathrm{mM}$ ABTS solution prepared in $0.1 \mathrm{M} \mathrm{Na}$ phosphate buffer at $\mathrm{pH} 6.0$ and $2 \mathrm{ml}$ of $0.1 \mathrm{mM} \mathrm{H}_{2} \mathrm{O}_{2}$ solution, brought to $30{ }^{\circ} \mathrm{C}$ before placing films (final $\mathrm{H}_{2} \mathrm{O}_{2}$ concentration in reaction mixtures was $8 \mu \mathrm{M}$ ). The Petri dishes were kept in an incubator at $30^{\circ} \mathrm{C}$ and stirred at $200 \mathrm{rpm}$ with a magnetic stirrer. The activity, monitored by measuring the reaction mixture absorbance at $412 \mathrm{~nm}$ at different time intervals, was determined from the slope of the initial linear portion of absorbance vs. time curve. The measurements were repeated for the remaining half of the film and the average of two measurements was considered in all film activity measurements. The activity was expressed as $U$ (0.001 absorbance change in one minute) per $\mathrm{cm}^{2}$ of the films.

\subsection{Determination of LPS affinity for films}

The affinity of LPS for alginate films was determined by modifying the method used by Appendini and Hotchkiss (1997). This method is based on considering the amount of enzyme activity retained in films after repeated activity measurements. In this study, after each activity measurement the films were additionally washed with cold distilled water. The films used in this study contained $0.52 \mathrm{mg} / \mathrm{cm}^{2}$ $\left(3252 \mathrm{U} / \mathrm{cm}^{2}\right)$ of LPS. The activity determination was conducted seven times and, after each activity determination, to remove the free enzyme and oxidized substrate absorbed, the films were washed by first placing for $3 \mathrm{~min}$ in a beaker containing $100 \mathrm{ml}$ of cold distilled water and second placing for $15 \mathrm{~min}$ in another beaker containing $250 \mathrm{ml}$ of cold distilled water, stirred magnetically. In these tests only, the immobilized LPS activity, measured at $412 \mathrm{~nm}$, was calculated by a two point assay, by reading standard reaction mixture absorbance at $0 \mathrm{~min}$ and 30 min of reaction $\left(\right.$ Activity $=\mathrm{Abs}_{30 \min }-\mathrm{Abs}_{0 \mathrm{~min}}$ ). This time period corresponds to the initial linear portion of absorbance vs. time curves. All measurements were applied for two films and averages were used to determine the effect of repeated activity measurements and washing on LPS activity retained in films.

\subsection{Characterization of LPS activity in films}

In all characterization studies, the characteristics were determined for immobilized LPS activity, in films at $30^{\circ} \mathrm{C}$, assayed by the standard method given in Section 2.6. All measurements were applied for two films and averages were used in determination of an effect on LPS activity expressed as $\mathrm{U} / \mathrm{cm}^{2}$ or percent initial activity.

The effect of prepared enzyme concentration on LPS activity of films was determined by measuring activity of films incorporated with LPS between 0.08 and $0.69 \mathrm{mg} /$ $\mathrm{cm}^{2}$ (516 and $4325 \mathrm{U} / \mathrm{cm}^{2}$ ).

The effect of $\mathrm{H}_{2} \mathrm{O}_{2}$ concentration on LPS activity of films was determined by measuring activity of films incorporated with $0.24-0.28 \mathrm{mg} / \mathrm{cm}^{2}\left(1200 \mathrm{U} / \mathrm{cm}^{2}\right)$ of LPS at different $\mathrm{H}_{2} \mathrm{O}_{2}$ concentrations (final concentrations in reaction mixture were between 2 and $24 \mu \mathrm{M}$ ).

The effect of temperature on LPS activity of films was determined by measuring activity of films incorporated with $0.23 \mathrm{mg} / \mathrm{cm}^{2}\left(998 \mathrm{U} / \mathrm{cm}^{2}\right)$ LPS between 4 and $30^{\circ} \mathrm{C}$. The activation energy $\left(E_{\mathrm{a}}\right)$ for the activity was calculated by using an Arrhenius plot, formed by plotting natural logarithm of activity $\left(\mathrm{U} / \mathrm{cm}^{2}\right)$ vs. reciprocal of temperature 
$\left(1 / T\left({ }^{\circ} \mathrm{K}\right)\right)$. The temperature quotient $\left(Q_{10}\right)$ of the enzyme activity was calculated from the equation $k_{2} / k_{1}=$ $\left(Q_{10}\right)^{\left(T_{2}-T_{1}\right) / 10}$, where $k$ is reaction rate (activity) and $T$ is temperature $\left({ }^{\circ} \mathrm{C}\right)$.

The effect of $\mathrm{pH}$ on LPS activity of films was determined by measuring enzyme activity of films incorporated with $0.19 \mathrm{mg} / \mathrm{cm}^{2}\left(1274 \mathrm{U} / \mathrm{cm}^{2}\right)$ of LPS in a reaction mixture containing $2 \mathrm{ml}$ of $0.3 \mathrm{mM} \mathrm{H} \mathrm{H}_{2} \mathrm{O}_{2}$ and $23 \mathrm{ml}$ of $0.65 \mathrm{mM}$ ABTS solution prepared in $0.1 \mathrm{M}$ acetate (at $\mathrm{pH} 3.0,4.0$ and 5.0) or Na phosphate (at pH 6.0 and 7.0) buffers.

The $\mathrm{pH}$ stabilities of LPS activity of films were determined by incubating films incorporated with $0.19 \mathrm{mg} / \mathrm{cm}^{2}$ $\left(1114 \mathrm{U} / \mathrm{cm}^{2}\right)$ LPS in $25 \mathrm{ml}$ of $0.1 \mathrm{M}$ acetate (at $\mathrm{pH} \mathrm{3.0,}$ 4.0 and 5.0 ) or $0.1 \mathrm{M} \mathrm{Na}$ phosphate (at $\mathrm{pH}$ 6.0) buffers at $4{ }^{\circ} \mathrm{C}$ for $24 \mathrm{~h}$. The remaining activities of the films were determined, at $\mathrm{pH} 6.0$, by using the following reaction mixture: $23 \mathrm{ml}$ of $0.65 \mathrm{mM}$ ABTS prepared in $0.1 \mathrm{M}$ Na phosphate buffer at $\mathrm{pH} 6.0$ and $2 \mathrm{ml}$ of $0.3 \mathrm{mM} \mathrm{H}_{2} \mathrm{O}_{2}$. The remaining LPS activities of films were given as percent of initial activity determined at $\mathrm{pH} 6.0$ by using films not incubated in buffer for $24 \mathrm{~h}$.

\subsection{Protein content}

Protein content was determined by the Lowry procedure, using bovine serum albumin as standard (Harris, 1987). An average of five measurements was used to calculate the protein content.

\section{Results and discussion}

\subsection{Partial purification of LPS}

In different partial purification studies, the LPS elution from Toyopearl-SP column was initiated when salt concentration was between 0.21 and $0.26 \mathrm{M}$, and ended when salt concentration reached between 0.42 and $0.51 \mathrm{M}$. In all elutions, the most active LPS fractions came between 0.3 and $0.4 \mathrm{M}$ salt concentrations. In batch 1 , a large protein peak, containing two fractions but lacking LPS activity, was

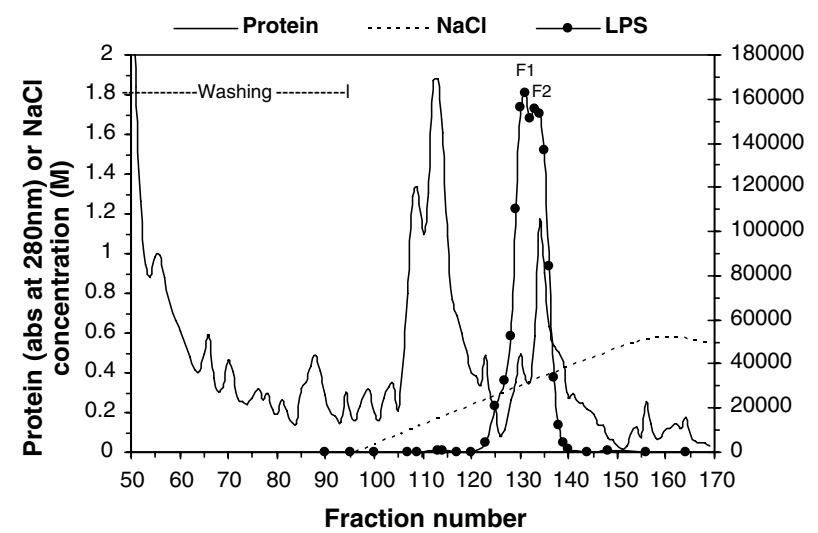

Fig. 1. LPS activity and protein profiles during Toyopearl-SP cationexchange chromatography of bovine rennet whey (batch no: 1).



Fig. 2. Protein profiles and LPS-active regions during Toyopearl-SP cation-exchange chromatography of bovine rennet whey (batches no: 2 and 3).

detected before LPS elution (Fig. 1). The elution profile of LPS activity in this batch suggested the presence of two major LPS enzyme forms in bovine whey $\left(F_{1}\right.$ and $F_{2}$ ). In batch 2 , conducted with another milk sample after several months, the LPS was not well separated from the major protein peak eluted before LPS-active fractions in batch 1 , and several protein peaks were observed in the enzyme active region (Fig. 2). This increased the protein content of the collected LPS-active fractions. However, because of the higher LPS activity of whey sample used in batch 2, the specific activity of enzyme and purification fold of separation were not significantly different from those of the same parameters in batch 1 (Table 1). In batch 3 , as occurred in batch 1, the major portion of LPS-active fractions was separated from the large protein peak, coming before enzyme. The bovine whey used in batch 3 contained the highest LPS activity, and its specific activity and recovery after column chromatography were also highest. The results of these chromatographic separations are quite different from those of Ye et al. (2000), that used

Table 1

Summary of partial purification studies of LPS from bovine rennet whey

\begin{tabular}{llllll}
\hline Batch Volume & $\mathrm{T}$ activity & $\mathrm{T}$ & $\mathrm{S}$ activity & Purity & Recovery
\end{tabular}

no. $(\mathrm{ml}) \quad(\mathrm{U}) \quad$ protein $(\mathrm{U} / \mathrm{mg})$ (fold) $\quad(\%)$ (mg)

1. Treatment of skim milk with rennet and centrifugation

$\begin{array}{lllllll}1 & 400 & 13,708,000 & 4374 & 3134 & 1 & 100\end{array}$

$\begin{array}{lllllll}2 & 400 & 18,824,000 & 5032 & 3741 & 1 & 100\end{array}$

$\begin{array}{lllllll}3 & 400 & 26,614,000 & 3632 & 7328 & 1 & 100\end{array}$

2. Toyopearl-SP cation-exchange chromatography

$\begin{array}{lllllll}1 & 150 & 3,651,750 & 76 & 48,049 & 15 & 27\end{array}$

$\begin{array}{lllllll}2 & 330 & 9,698,700 & 182 & 53,290 & 14 & 52\end{array}$

$\begin{array}{lllllll}3 & 248 & 21,588,400 & 95 & 227,246 & 31 & 81\end{array}$

3. $24 \mathrm{~h}$ Dialysis at $4{ }^{\circ} \mathrm{C}$

$1 \quad \mathrm{Nd}^{\mathrm{a}} \quad \mathrm{Nd} \quad \mathrm{Nd} \quad \mathrm{Nd} \quad \mathrm{Nd} \quad \mathrm{Nd}$

$\begin{array}{lllllll}2 & 300 & 9,447,000 & 153 & 61,745 & 17 & 50\end{array}$

$\begin{array}{lllllll}3 & 267 & 16,950,495 & 74 & 229,061 & 31 & 64\end{array}$

${ }^{\mathrm{a}}$ Not determined 
the same chromatographic procedure for the partial purification of LPS from bovine whey. These workers eluted LPS from the column between 0.16 and $0.19 \mathrm{M}$ salt concentrations as a single peak. Also, the LPS-free large protein fraction containing two protein peaks, reported as lactoferrin-a and lactoferrin-b by these workers, were eluted from the column between 0.42 and $0.55 \mathrm{M}$ salt concentrations. Ozdemir, Aygul, and Küfrevioglu (2001), on the other hand, determined two LPS fractions after cation-exchange chromatography on CM-Sephadex C-50. However, the LPS gave a single band in SDS-PAGE electrophoresis. Watanabe et al. (2000) explained the heterogenic profiles of LPS in disk-electrophoresis and ionexhange chromatography by differences in the N-terminal amino acid residues of different LPS forms. However, as LPS is a glycoprotein that contains almost $10 \%$ carbohydrate, such an heterogeneity may also be related to the type of carbohydrate attached to the enzyme by glycosylation. In fact, Wolf, Ferrari, Traversa, and Biemann (2000) reported that the glycosylation sites of LPS are fully occupied with different high mannose and complex structures and this may vary molecular weight of LPS between 74,850 and 79,188 Da.

\subsection{Stability of the prepared LPS during storage}

In the literature, the general stabilizing effect of dextran on enzymes was reported by different workers (de la Casa, Guisan, Sanchez-Montero, \& Sinisterra, 2002; Sasahara, McPhie, \& Minton, 2003; Wasserman, 1984). The dextran produced by bacterial fermentation with Leuconostoc mesenteroides presents no toxicological concerns and it has been approved for food applications (Anonymous, 2000). As shown in Table 2, different batches of enzymes, lyophilized by using dextran, maintained almost $70-75 \%$ of their initial activity after $1-2$ months at $-18^{\circ} \mathrm{C}$. Further storage of one of the enzymes for almost 5 months increased the loss of enzyme activity only slightly. Thus, it appears that most of the activity in lyophilized LPS used in film making

Table 2

Stability of partially purified LPS lyophilized by using dextran as supporting material and stored at $-18{ }^{\circ} \mathrm{C}$

\begin{tabular}{lrlr}
\hline Batch no. & Storage time (days) & \multicolumn{2}{l}{ Remaining activity } \\
\cline { 3 - 4 } & & U/mg powder & $\%$ \\
\hline 1 & 0 & 6271 & 100 \\
& 28 & 4542 & 72 \\
& 48 & 4767 & 76 \\
& 161 & 3768 & 60 \\
2 & 0 & 4363 & 100 \\
& 32 & 4424 & 101 \\
& 70 & 3005 & 69 \\
3 & 0 & 6576 & 100 \\
& 20 & 5750 & 87 \\
& 33 & 4621 & 70 \\
\hline
\end{tabular}

showed sufficient stability during several months of frozen storage.

\subsection{Affinity of LPS for alginate films}

As seen in Fig. 3, after the first activity measurement, conducted with $30 \mathrm{~min}$ of reaction at $30^{\circ} \mathrm{C}$ and washing, the films incorporated with $0.52 \mathrm{mg} / \mathrm{cm}^{2}$ of LPS maintained almost $80 \%$ of their activity. Thus, it is clear that most of the LPS-incorporated into alginate films was immobilized. In characterization studies, the LPS content of films was equal to almost half of the LPS content of films used in repeated activity measurements. Thus, little LPS leakage from the films is expected during characterization studies. In fact, in preliminary release tests conducted at $4{ }^{\circ} \mathrm{C}$ in distilled water (volume: $50 \mathrm{ml}$, stirring rate: $200 \mathrm{rpm}$ ) for $1800 \mathrm{~min}$, no LPS activity release was determined from alginate films (area: $75.4 \mathrm{~cm}^{2}$ ) incorporated with low amounts of LPS preparation $(0.15 \mathrm{mg} /$ $\mathrm{cm}^{2}$ or $941 \mathrm{U} / \mathrm{cm}^{2}$ ). The alginate films are composed of linear copolymers of D-mannuronic acid and L-guluronic acid that are cross-linked by the $\mathrm{CaCl}_{2}$ (Lindstrom et al., 1992). Because of its high isoelectric point (pI 9.6), the LPS is mainly positively charged in the $\mathrm{pH}$ values studied. Thus, the enzyme may bind to films by the negatively charged carboxylic acid groups on polymeric chains of alginate. In this study, the LPS was prepared with dextran. Thus, the H-bonding of dextran to enzyme and alginate can also make a contribution to the immobilization of enzyme. After the third washing, on the other hand, a moderate drop (almost $40 \%$ ) of enzyme activity was observed, whereas significant drops in activity occurred in the following washings. The reductions of enzyme activity at the latter stages might be related to the inhibitory effect of the substrate's blue coloured oxidation products absorbed by the films and could not be effectively removed by washing.

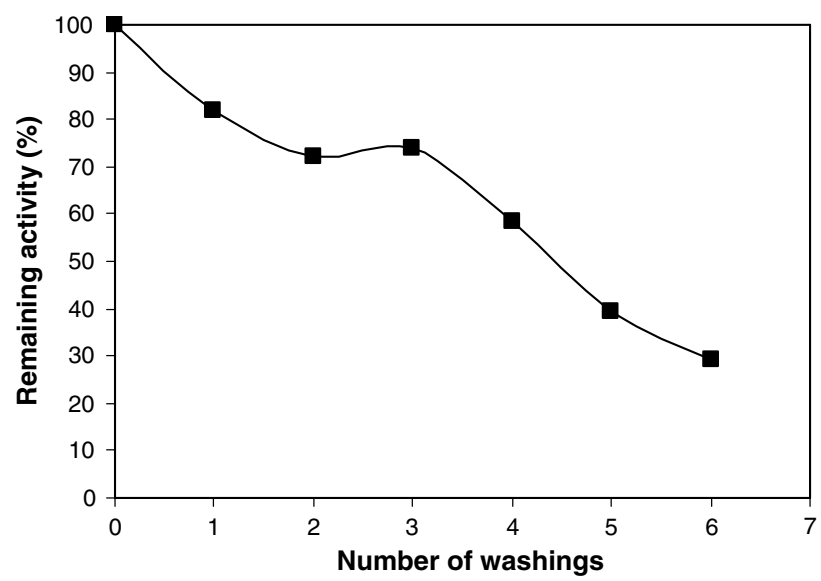

Fig. 3. Stability of LPS activity of alginate films during repeated activity measurements and washings. 
3.4. Effect of enzyme preparation concentration on LPS activity of films

Incorporation of LPS (up to $0.16 \mathrm{mg} / \mathrm{cm}^{2}$ ) did not notably change the LPS activity of alginate films in the presence of $8 \mu \mathrm{M} \mathrm{H}_{2} \mathrm{O}_{2}$ (Fig. 4). The initial lag period suggests the necessity of reaching a critical LPS concentration at the film surface where catalytic activity of films is controlled. Between 0.16 and $0.52 \mathrm{mg} / \mathrm{cm}^{2}$ LPS concentrations, the increase of incorporated enzyme concentration increased the LPS activity of films linearly. However, at $0.69 \mathrm{mg} /$ $\mathrm{cm}^{2}$ LPS concentration, the slope of the curve increased further. The increase of activity at the highest LPS concentration may be due to the leakage of part of the enzyme in films to the reaction mixture.

\subsection{Effect of $\mathrm{H}_{2} \mathrm{O}_{2}$ concentration on LPS activity of films}

The effect of $\mathrm{H}_{2} \mathrm{O}_{2}$ on enzyme activity of alginate films incorporated with $0.24-0.28 \mathrm{mg} / \mathrm{cm}^{2}\left(1200 \mathrm{U} / \mathrm{cm}^{2}\right)$ LPS was determined between 2 and $24 \mu \mathrm{M} \mathrm{H}_{2} \mathrm{O}_{2}$ concentrations. As seen in Fig. 5, increase of $\mathrm{H}_{2} \mathrm{O}_{2}$ concentration increased the LPS activity of alginate films. In the $\mathrm{H}_{2} \mathrm{O}_{2}$ concentration range studied, the activities of films changed between 0.04 and $1.6 \mathrm{U} / \mathrm{cm}^{2}$, and $1.5-2.5$-fold increase in LPS activity was observed when $\mathrm{H}_{2} \mathrm{O}_{2}$ concentration was increased two-fold. The $\mathrm{H}_{2} \mathrm{O}_{2}$, an important component of the LPS antimicrobial mechanism, is a toxic compound, but it was reported that, at low concentrations (less than $100 \mu \mathrm{M})$ and in the presence of LPS and thiocyanate, mammalian cells are protected from this toxicity (Seifu et al., 2005). Thus, it seems that the obtained films showed good LPS activity at $\mathrm{H}_{2} \mathrm{O}_{2}$ concentrations not toxic to mammalian cells. Also, it appears that, by regulating the concentration of $\mathrm{H}_{2} \mathrm{O}_{2}$, it is possible to form and control the rate of an antimicrobial mechanism in alginate films incorporated with small amounts of LPS.

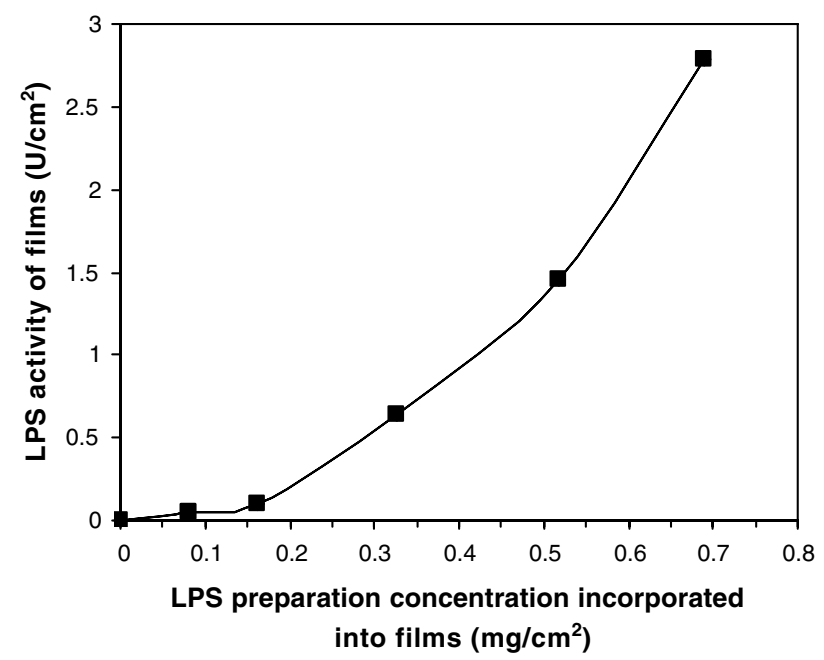

Fig. 4. Effect of enzyme preparation concentration on LPS activity of alginate films $\left(\mathrm{H}_{2} \mathrm{O}_{2}\right.$ concentration : $\left.8 \mu \mathrm{M}\right)$.

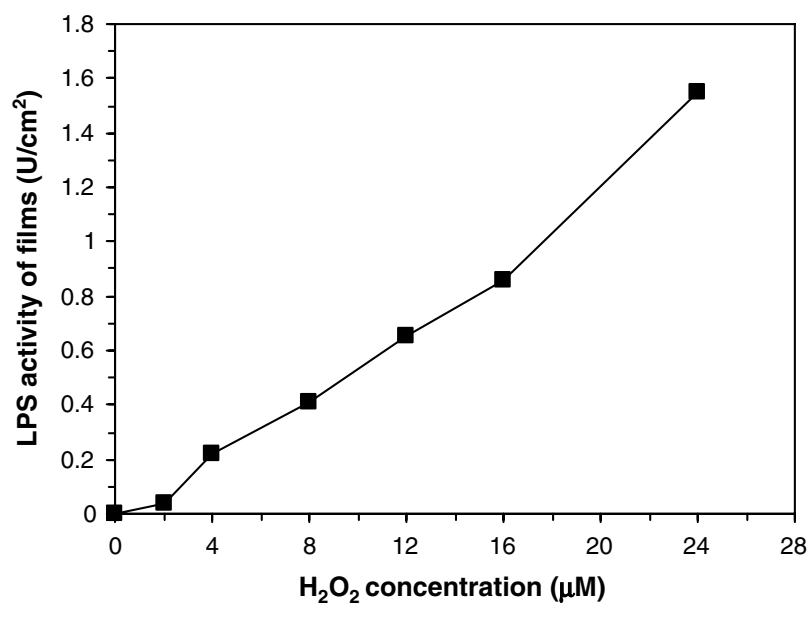

Fig. 5. Effect of $\mathrm{H}_{2} \mathrm{O}_{2}$ concentration on LPS activity of alginate films.

\subsection{Effect of temperature on LPS activity of films}

The effect of temperature on LPS activity immobilized in alginate films was determined between 4 and $30^{\circ} \mathrm{C}$, a temperature range to which packaged food is generally exposed. As seen in Fig. 6, between 4 and $16{ }^{\circ} \mathrm{C}$, an increase of temperature increased the enzyme activity of films. In this temperature range, a $10^{\circ} \mathrm{C}$ change in temperature caused a 1.69 -fold $\left(Q_{10}\right)$ change in LPS activity. The activation energy of enzyme between 4 and $16{ }^{\circ} \mathrm{C}$ was also calculated to be $34.6 \mathrm{~kJ} / \mathrm{mol}$. These $E_{\mathrm{a}}$ and $Q_{10}$ values indicate the low dependency of LPS activity in alginate films on temperature change. Between 16 and $30^{\circ} \mathrm{C}$, on the other hand, the temperature had almost no effect on LPS activity of films. The low temperature dependency of the immobilized LPS in alginate films is an advantage for food applications of the enzyme when a certain amount of enzyme activity is desired in the product under variable processing and/or storage temperatures.

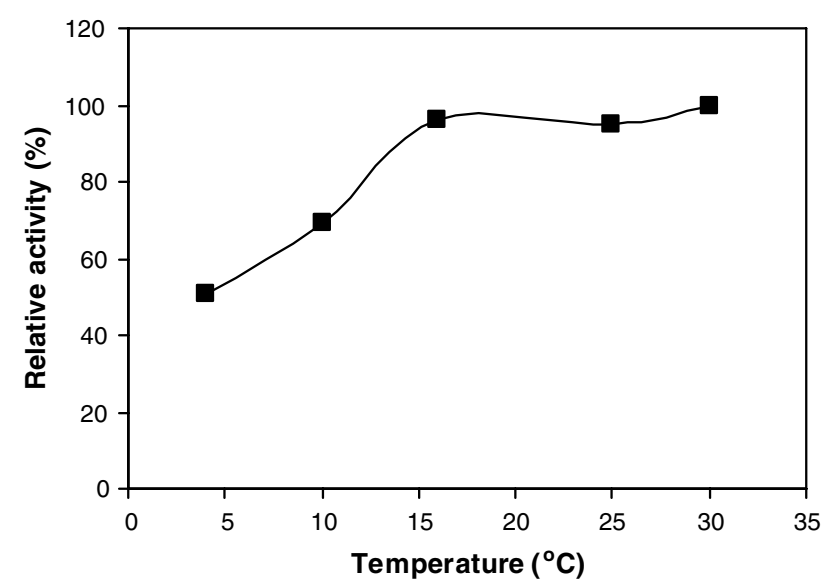

Fig. 6. Effect of temperature on LPS activity of alginate films. 


\subsection{Effect of pH on LPS activity of films}

The effect of $\mathrm{pH}$ on LPS activity was determined between $\mathrm{pH} 3.0$ and 7.0. At $\mathrm{pH}$ 4.0, the activity of enzyme was minimum (Fig. 7). However, the enzyme showed almost $30 \%$ of its activity at this $\mathrm{pH}$ value. The optimum activity of enzyme was at $\mathrm{pH} 6.0$, but the enzyme is also very active at $\mathrm{pH} 7.0$. However, at $\mathrm{pH} 7.0$ the alginate films were decomposed during activity measurements. It is likely that the decomposition of films occurred because of the loosening of cross-linking interactions at this $\mathrm{pH}$ by the effect of oxidative changes catalyzed by LPS in the reaction mixture. The enzyme, on the other hand, maintained minimum $50 \%$ of its activity at $\mathrm{pH} 3.0$ and 5.0 . The broad $\mathrm{pH}$ spectrum of LPS suggests the suitability of using alginate films incorporated with LPS as a natural antimicrobial system for different foods. The $\mathrm{pH}$ optimum and profile of immobilized LPS in alginate films were almost same or not significantly different from that reported for soluble LPS in bovine milk. For example, Ozdemir et al. (2001) reported the optimum $\mathrm{pH}$ of soluble LPS to be 6.0 for ABTS substrate. Blel, Guingamp, Gaillard, and Humbert (2001) showed that the LPS in milk maintained a minimum $50 \%$ of its activity between pH 6.0 and 8.0 and it exhibited optimum activity at $\mathrm{pH} 6.7$ against ABTS substrate. In their detailed review, Seifu et al. (2005) also reported that the optimum $\mathrm{pH}$ of soluble bovine LPS was between 5.0 and 6.0, depending on the concentrations of the substrates ABTS and $\mathrm{H}_{2} \mathrm{O}_{2}$ used in the assay.

\section{8. pH stability of LPS activity of films}

The stability tests showed that the LPS lost almost $90 \%$ of its activity in $24 \mathrm{~h}$ at $\mathrm{pH} 3.0$ (Fig. 8). However, the enzyme activity is very stable between $\mathrm{pH} 4.0$ and 6.0, a range where most foods fall in this category. The retention of most of the enzyme activity in alginate films in this $\mathrm{pH}$

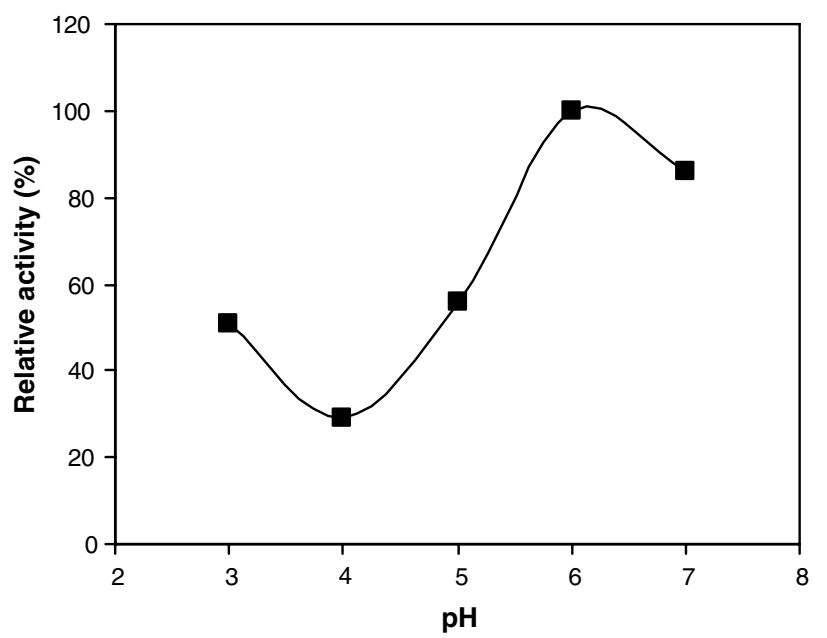

Fig. 7. Effect of $\mathrm{pH}$ on LPS activity of alginate films.

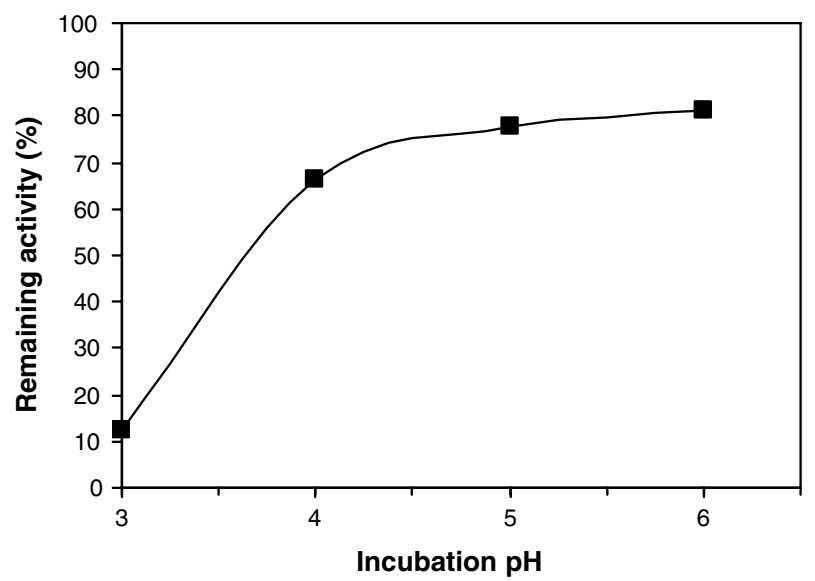

Fig. 8. $\mathrm{pH}$ stability of LPS activity of alginate films (Incubation period $24 \mathrm{~h}$ at $\left.4{ }^{\circ} \mathrm{C}\right)$.

range after $24 \mathrm{~h}$ once more showed the strong binding of LPS by the alginate films.

\section{Conclusions}

The preparations obtained by lyophilization of purified bovine LPS, by using dextran as supporting material, showed sufficient stability for several months at $-18^{\circ} \mathrm{C}$. The incorporation of prepared LPS into alginate films caused the immobilization of most of the enzyme. Thus, the antimicrobial effect of LPS-incorporated alginate films might be controlled by the enzymatic transformation of antimicrobial compounds from the thiocyanate incorporated into films, added to food or naturally occurring in food. The high LPS activity of films at low $\mathrm{H}_{2} \mathrm{O}_{2}$ concentrations, very small effect of temperature changes on immobilized enzyme activity, broad $\mathrm{pH}$ range and $\mathrm{pH}$ stability of enzyme activity, all show the good potential of LPS-incorporated alginate films in forming a natural antimicrobial mechanism in different foods. Further studies are continuing in our laboratory to test the antimicrobial effect of LPS-incorporated alginate films on different microorganisms.

\section{Acknowledgement}

This project (MISAG \# 221) was funded by the TÜBITAAK (Scientific and Technical Research Council of Turkey).

\section{References}

Anonymous (2000). Opinion of the scientific committee on food on a dextran preparation, produced using Leuconostoc mesenteroides, Saccharomyces cerevisiae and Lacrobacillus spp. as a novel food ingredient in bakery products ( pp 7). European Commission Health and Consumer Protection Directorate-General, CS/NF/DOS/7/ADD 3 FINAL

Appendini, P., \& Hotchkiss, J. H. (1997). Immobilization of lysozyme on food contact polymers as potential antimicrobial films. Packaging Technology and Science, 10, 271-279. 
Appendini, P., \& Hotchkiss, J. H. (2002). Review of antimicrobial food packaging. Innovative Food Science and Emerging Technologies, 3, 113-126.

Blel, M., Guingamp, M. F., Gaillard, J. L., \& Humbert, G. (2001). Improvement of a method for the measurement of lactoperoxidase activity in milk. International Diary Journal, 11, 795-799.

Boussouel, N., Mathieu, F., Revol-Junelles, A. M., \& Milliere, J. B. (2000). Effects of combinations of lactoperoxidase system and nisin on the behaviour of Listeria monocytogenes ATCC 15313 in skim milk. International Journal of Food Microbiology, 61, 169-175.

Branen, J. K., \& Davidson, P. M. (2004). Enhancement of nisin, lysozyme, and monolaurin antimicrobial activities by ethylenediaminetetraacetic acid and lactoferrin. International Journal of Food Microbiology, 90, 63-74.

Cha, D. S., Choi, J. H., Chinnan, M. S., \& Park, H. J. (2002). Antimicrobial films based on Na-alginate and $\kappa$-carrageenan. Lebensmittel Wiss. und Technologie, 35(8), 715-719.

Dawson, P., Hoffman, K., \& Han, I. (2000) Biocide-impregnated food films to inhibit food pathogens. Second NSF International Conference on Food Safety, October, (pp. 11-13) Savannah, GA.

de la Casa, R. M., Guisan, J. M., Sanchez-Montero, J. M., \& Sinisterra, J. V. (2002). Modification of the activities of two different lipases from Candida rugosa with dextrans. Enzyme and Microbial Technology, 30, $30-40$.

De Roever, C. (1998). Microbiological safety evaluations and recommendations on fresh produce. Food Control, 9(6), 321-347.

Dufour, M., Simmonds, R. S., \& Bramer, P. J. (2003). Development of a method to quantify in vitro the synergistic activity of "natural" antimicrobials. International Journal o Food Microbiology, 85, $249-259$.

Elliot, R. M., McLay, J. C., Kennedy, M. J., \& Simmonds, R. S. (2004). Inhibition of foodborne bacteria by the lactoperoxidase system in a beef cube system. International Journal of Food Microbiology, 91, 73-81.

Han, J. H. (2000). Antimicrobial food packaging. Food Technology, 54(3), $56-65$.

Harris, D. A. (1987). Spectrophotometric assays. In D. A. Harris \& C. L. Bashford (Eds.), Spectrophotometry and spectrofluorometry (pp. 59-60). Oxford: I.R.L. Press.

Hoffman, KL., Han, I. Y., \& Dawson, P. L. (2001). Antimicrobial effects of corn zein films impregnated with nisin, lauric acid, and EDTA. Journal of Food Protection, 64(6), 885-889.

Jacob, B. M., Antony, E., Sreekumar, B., \& Haridas, M. (2000). Thiocyanate mediated antifungal and antibacterial property of goat milk lactoperoxidase. Life Sciences, 66(25), 2433-2439.

Janes, M. E., Kooshesh, S., \& Johnson, M. G. (2002). Control of Listeria monocytogenes on the surface of refrigerated, ready-to-eat chicken coated with edible zein film coatings containing nisin and/or calcium propionate. Journal of Food Science, 67, 2754-2757.

Kennedy, M., O'Rourke, A. L., McLay, J., \& Simmonds, R. (2000). Use of ground beef model to assess the effect of the lactoperoxidase system on the growth of Escherichia coli O157:H7, Listeria monocytogenes and Staphylococcus aureus in red meat. International Journal of Food Microbiology, 57, 147-158.

Labuza, T. P., \& Breene, W. M. (1989). Applications of "active packaging" for improvement of shelf-life and nutritional quality of fresh and extended shelf-life foods. Journal of Food Processing and Preservation, 13, 1-69.

Lindstrom, T. R., Morimoto, K., \& Cante, C. J. (1992). Edible films and coatings. In Y. H. Hui (Ed.). Encyclopedia of food Science and Technology (Vol. 2, pp. 59-663). New York: John Wiley and Sons. Inc.

Min, S., Harris, L., \& Krochta, J. M. (2005b). Antimicrobial effects of lactoferrin, lysozyme, and the lactoperoxidase system and edible whey protein films incorporating the lactoperoxidase system against Salmonella enterica and Escherichia coli O157:H7. Journal of Food Science, $70,332-338$.
Min, S., Harris, L., \& Krochta, J. M. (2005c). Listeria monocytogenes inhibition by whey protein films and coatings incorporating the lactoperoxidase system. Journal of Food Science, 70, $317-324$.

Min, S., \& Krochta, J. M. (2005a). Inhibition of Penicillium commune by edible whey protein films incorporating lactoferrin, lactoferrin hydrosylate, and lactoperoxidase systems. Journal of Food Science, 70, 87-94.

Ozdemir, H., Aygul, I., \& Küfrevioglu, O. I. (2001). Purification of lactoperoxidase from bovine milk and investigation of the kinetic properties. Preparative Biochemistry and Biotechnology, 31, 125-134.

Padgett, T., Han, I. Y., \& Dawson, P. L. (1998). Incorporation of foodgrade antimicrobial compounds into biodegradable packaging films. Journal of Food Protection, 61(10), 1330-1335.

Padgett, T., Han, I. Y., \& Dawson, P. L. (2000). Effect of lauric acid addition on the antimicrobial efficacy and water permeability of corn zein films containing nisin. Journal of Food Processing and Preservation, 24, 423-432.

Pakkanen, R., \& Aalto, J. (1997). Growth factors and antimicrobial factors of bovine colostrums. International Dairy Journal, 7, 285-297.

Park, S. I., Daeschel, M. A., \& Zhao, Y. (2004). Functional properties of antimicrobial lysozyme-chitosan composite films. Journal of Food Science, 69(8), 215-221.

Pruitt, K. M., Tenovuo, J., Andrews, R. W., \& McKane, T. (1982). Lactoperoxidase-catalyzed oxidation of thiocyanate: Polarographic study of the oxidation products. Biochemistry, 21, 562-567.

Quintavalla, S., \& Vicini, L. (2002). Antimicrobial food packaging in meat industry. Meat Science, 62, 373-380.

Sasahara, K., McPhie, P., \& Minton, A. P. (2003). Effect of dextran on protein stability and conformation attributed to macromolecular crowding. Journal of Molecular Biology, 326, 1227-1237.

Seifu, E., Buys, E. M., \& Donkin, E. F. (2004). Quality aspects of gouda cheese made from goat milk preserved by the lactoperoxidase system. International Dairy Journal, 14, 581-589.

Seifu, E., Buys, E. M., \& Donkin, E. F. (2005). Significance of the lactoperoxidase system in the dairy industry and its potential applications: A Review. Trends in Food Science \& Technology, 16, 1-18.

Suppakul, P., Miltz, J., Sonneveld, K., \& Bigger, S. W. (2003). Active packaging technologies with an emphasis on antimicrobial packaging and its applications. Journal of Food Science, 68, 408-420.

Teerakarn, A., Hirt, D. E., Acton, J. C., Rieck, J. R., \& Dawson, P. L. (2002). Nisin diffusion in protein films: Effects of film type and temperature. Journal of Food Science, 67(8), 3019-3025.

Touch, V., Hayakawa, S., Yamada, S., \& Kaneko, S. (2004). Effects of a lactoperoxidase-thiocyanate-hydrogen peroxide system on Salmonella enteritidis in animal or vegetable foods. International Journal of Food Microbiology, 93, 175-183.

Wasserman, B. P. (1984). Thermostable enzyme Production. Food Technology, 78-89.

Watanabe, S., Murata, S., Kumura, H., Nakamura, S., Bollen, A., Moguilevsky, N., et al. (2000). Bovine lactoperoxidase and its recombinant: Comparison of structure and some biochemical properties. Biochemical and Biophysical Research Communications, 274, 756-761.

Wolf, S. M., Ferrari, R. P., Traversa, S., \& Biemann, K. (2000). Determination of the carbohydrate composition and the disulfide bond linkages of bovine lactoperoxidase by mass spectrometry. Journal of Mass Spectrometry, 35, 210-217.

Ye, X., Yoshida, S., \& Ng, T. B. (2000). Isolation of lactoperoxidase, lactoferrin, $\alpha$-lactalbumin, $\beta$-lactoglobulin $\mathrm{B}$ and $\beta$-lactoglobulin A from bovine rennet whey using ion exchange chromatography. The International Journal of Biochemistry \& Cell Biology, 32, 1143-1150.

Zapico, P., Medina, M., Gaya, P., \& Nunez, M. (1998). Synergistic affect of nisin and the lactoperoxidase system on Listeria monocytogenes in skim milk. International Journal of Food Microbiology, 40, 35-42. 